УДК: 78:796/799-052]:37.014.13

\title{
МОДЕЛЬ ФОРМУВАННЯ ІНДИВІДУАЛЬНОГО СТИЛЮ ПРОФЕСІЙНОЇ ДІЯЛЬНОСТІ МАЙБУТНІХ УЧИТЕЛІВ ФІЗИЧНОЇ КУЛЬТУРИ У ПРОЦЕСІ ПЕДАГОГІЧНОЇ ПРАКТИКИ
}

Тетяна Бугаєнко,

викладач кафедри здоров'я, фізичної терапї, реабілітації та ерготерапії

Сумського державного педагогічного університету імені А. С. Макаренка

клЮчОВІ
СЛОВА:
модель,
учитель фізичної
культури,
педагогічна
практика,
індивідуальний
стиль професійної
діяльності

\begin{abstract}
Реферат
У даній статті розглядається зміст моделі формування індивідуального стилю професійної діяльності майбутніх учителів фізичної культури у процесі педагогічної практики. Визначено та обгрунтовано педагогічні умови, що безпосередньо впливають на ефективність цього процесу. Спроектовану модель деталізовано складовими методологічно-цільового, організаційнозмістовного і діагностичного блоків, у яких відображено мету освітнього процесу, сформульованих 3 урахуванням цивілізаційних запитів і соціального замовлення. Методологічно-цільовий блок містить основну ідею, якій підпорядковані всі складові елементи моделі, визначає здатність бачити загальний хід процесу і випереджувально коригувати його хід. Він визначає стратегію реалізації моделі і включає в себе мету, методологічні принципи й універсальні підходи становлення стилю. Організаційно-змістовний блок розкриває компонентний склад індивідуального стилю професійної діяльності; комплекс умов, форм, методів і засобів роботи, що забезпечують результативність реалізації моделі. Також охарактеризовано сукупність зовнішніх і внутрішніх причин, рушійних сил і явищ, окремі риси процесу становлення індивідуального стилю діяльності майбутнього вчителя. Розкрито зміст етапів його формування у майбутніх учителів фізичної культури в процесі педагогічної практики, сконструйовані таким чином, щоб кожний з наступних етапів містив елементи констатації стану стилю. Часові межі кожного етапу окреслені, з одного боку, індивідуально-психологічними властивостями студентів-практикантів, а 3 іншого, специфікою конкретних умов життедіяльності у процесі здобуття фахової освіти. Діагностичний блок спрямований на визначення ефекту від реалізації моделі та порівняння отриманих результатів. Він відображає інтеграцію таких інструментальних систем, як: структура стилю, критерії та рівні його сформованості, дає уявлення про механізм реалізації розробленої моделі через взаємозв'язок діагностичних процедур, визначення етапів становлення стилю i критеріально спрямований уплив організаційно-педагогічних умов на компоненти індивідуального стилю.
\end{abstract}

Постановка проблеми. В умовах сучасних суспільно-економічних та соціокультурних трансформацій, що відбуваються в Україні, актуалізується проблема реалізації творчого потенціалу людини у різних сферах буття, прогнозування очікуваних результатів розвитку індивідуально-особистісних властивостей майбутніх фахівців у межах професійної діяльності. Відтак, у царині філософії, психології, педагогіки, соціології та субдисциплін означених наук посилюється увага до обгрунтування істотних характеристик індивідуальності людини, розгляду механізмів і алгоритмів формування та подальшого розвитку індивідуального стилю професійної діяльності (далі - ІСПД) як провідного чинника успішного адаптування індивіда в різних ситуаціях самореалізації.

Аналіз останніх досліджень. Це посилює вимоги до якості професійної підготовки майбутніх педагогів у цілому й учителів фізичної культури зокрема, i концептуалізується в Конституції та Законах України «Про освіту» (2017), «Про вищу освіту» (2014), «Про фізичну культуру і спорт» (1993), «Про внесення змін до деяких законів України щодо підтримки дитячоюнацького спорту та фізичного виховання дітей» (2015), в листі Комітету з фізичного виховання та спорту Міністерства освіти i науки України «Про підвищення рівня навчально-виховної роботи 3 фізичного виховання в навчальних закладах» (2015), Указі Президента «Про Національну стратегію з оздоровчої рухової активності в Україні на період до 2025 року «Рухова активність - здоровий спосіб життя - здорова нація» (2016), Державному соціальному стандарті у сфері фізичної культури і спорту (2013), Державній цільовій програмі розвитку фізичної культури і спорту на період до 2020 (2017), Концепції Нової української школи (2017) та інших чинних документах.

Отже, проблема формування індивідуально стилю професійної діяльності майбутніх учителів фізичної культури $\epsilon$ актуальною і недостатньо висвітленою в суспільно-гуманітарній і нормативнозаконодавчій площині. 
Метою даної статті $€$ обгрунтування змісту i структури теоретичної моделі формування індивідуального стилю професійної діяльності майбутніх учителів фізичної культури у процесі педагогічної практики.

Виклад основного матеріалу. Моделювання - це найпоширеніший метод дослідження об'єктів різної природи, в тому числі й об'єктів складної соціальної системи. Саме тому цей метод широко використовується при проведенні наукових досліджень. У психології модель розглядається як ідеальна копія реального об’єкта, яка відтворює не всі явища в цілому, a лише найбільш істотні його риси i властивості $[4$, с. 11]. С. Гончаренко у педагогічних міркуваннях пропонує під моделлю розуміти еталон, стандарт, зразок, примірник чогось; схему для пояснення якогось явища або процесу [1, с. 195]. У межах нашого дослідження, найбільш прийнятним $\epsilon$ філософське тлумачення поняття «модель» як «речової, знакової або уявної (мисленнєвої) системи, що відтворює, імітує чи відображає принципи внутрішньої організації або функціонування певних властивостей, ознак і характеристик об'єкта дослідження (оригіналу), безпосередне вивчення якого неможливе, ускладнене або недоцільне і може замінити цей об'єкт у пізнавальному процесі 3 метою одержання нових знань про нього» [5, с. 394].

Окремої уваги заслуговує традиційна для педагогічних досліджень модель дидактичної системи особистісноорієнтованої підготовки студентів у педагогічному ВН3, запропонована В. Мішагіним. Вона, як і більшість наявних у науковій літературі, включає в себе п'ять компонентів: цільовий, мотиваційний, змістовий, організаційний та оцінний [3, c. 15-23].

Цільовий компонент моделі педагогічного процесу включає цілі i завдання педагогічної діяльності; мотиваційним передбачено активізацію майбутніх учителів фізичної культури у процесі професійної підготовки; організаційний спрямований на керування освітнім процесом та презентацію студентам трансформованих прикладів активності й самоврядування професійної підготовки; оцінний дає можливість викладачу оцінити рівень особистісної та професійної підготовленості майбутніх учителів фізичної культури, а студентам - визначити свої навчальні можливості та провести експертну оцінку ефективності особистісноорієнтованого навчання.

Дана модель ураховує значну кількість факторів професійної підготовки майбутніх учителів, але вони складно піддаються систематизації, і відповідно, роблять модель занадто громіздкою й ставлять під сумнів можливість іiі впровадження у повсякденну педагогічну практику.

В аналізованих нами моделях недостатньо висвітлено психологопедагогічні механізми актуалізації й активізації формування ІСПД. Найчастіше основні цілі освітньо-професійної підготовки майбутніх учителів фізичної культури автори пов'язують із запитами суспільства, а також визначають можливості ïx досягнення у доцільній організації професійної підготовки фахівців.

Запропонована нами модель формування ІСПД майбутніх учителів фізичної культури має чітко визначену мету й завдання, грунтується на актуальних методологічних підходах, передбачає створення відповідних педагогічних умов, визначає етапи формування ІСПД, критерії i рівні, за якими здійснюється контроль за позитивним розгортанням процесу, спрямовується на кінцевий результат.

Під моделлю формування індивідуального стилю професійної діяльності майбутніх учителів фізичної культури у процесі педагогічної практики ми розуміємо опис і теоретичне обгрунтування структурних компонентів даного процесу.

Упровадження розробленої педагогічної моделі грунтується на таких педагогічних умовах:

- реалізація ідей індивідуального підходу в навчально-пізнавальній діяльності майбутніх учителів фізичної культури у процесі педагогічної практики, та педагогічний моніторинг формування індивідуального стилю педагогічної діяльності;

- надання студентам-практикантам педагогічної підтримки, у ситуаціях суб'єктсуб'єктної психолого-діалогічної взаємодії 
зорієнтованої на формування індивідуального стилю педагогічної діяльності та 3 метою подолання ускладненої комунікації 3 суб'єктами педагогічного процесу;

- забезпечення майбутніх учителів фізичної культури системою пошуковоситуативних завдань 3 можливим поетапним зростанням рівня їх складності у процесі педагогічної практики;

- наскрізний характер педагогічної практики із залученням студентів у професійну, навчальну, навчально-спортивну діяльність упродовж усього навчання, діагностика і корекція стану сформованості індивідуального стилю професійної діяльності майбутніх учителів фізичної культури, методичне забезпечення експериментально практичної реалізації моніторингу якості формування індивідуального стилю професійної діяльності.

Важливою є позиція про неприпустимість ототожнення педагогічного процесу, спрямованого на формування ІСПД, із здобуттям освіти. Тому в моделюванні грунтувалися на ідеях зарубіжного досвіду стосовно підготовки вчителів фізичної культури, де надаються пріоритети творчій діяльності викладачів і студентів як суб'єктів освітнього процесу.

Розроблену модель презентовано на рис. 1. у вигляді складної граф-схеми, яка схематично відтворює педагогічний процес, що здійснюеться відповідно до соціального замовлення держави на підготовку кваліфікованих учителів фізичної культури зі сформованим індивідуальним стилем професійної педагогічної діяльності та грунтується на пріоритетних цінностях суспільства сталого розвитку.

Спроектовану модель деталізовано складовими методологічно-иільового, організаиійно-змістового $i$ діагностичного блоків, в яких відображено мету освітнього процесу, сформульовану 3 урахуванням цивілізаційних запитів i соціального замовлення.

Методологічно-цільовий блок містить основну ідею, якій підпорядковані всі складові елементи моделі, визначає здатність бачити загальний хід процесу i випереджувально коригувати його хід, включає мету, методологічні принципи $\mathrm{i}$ універсальні підходи становлення стилю; охоплює мету, методологічні підходи, систему дидактичних принципів, що сприяють розвитку кар'єрної компетентності майбутніх учителів фізичної культури.

Організаційно-змістовий

блок охоплює весь компонентний склад ІСПД, комплекс організаційно-педагогічних умов, форм, методів i засобів роботи, що забезпечують результативність реалізації моделі, сукупність зовнішніх і внутрішніх причин, рушійних сил і явищ, окремі риси процесу становлення індивідуального стилю діяльності майбутнього вчителя - фактори i етапи стилеоутворення, суб'єкт-суб'єктну позицію андрагогії майбутнього вчителя; етапи та інтегративну складову теорії i практики ІСПД.

До складу організаційно-змістового блоку моделі входять чинники формування ІСПД майбутніх учителів фізичної культури, що охоплюють: знання суті професійного розвитку i саморозвитку вчителя фізичної культури; уміння i навички 3 організації й методики формування ІСПД майбутніх учителів фізичної культури; наявність індивідуально-особистісних і професійно значущих якостей; практичний досвід формування власного ІСПД; позитивну емоційно-мотиваційну спрямованість на формування ІСПД. Відповідно до цих чинників визначено педагогічні умови формування ІСПД майбутніх учителів фізичної культури.. До складу блоку також включено форми і методи навчання, що зумовлюють формування ІСПД майбутніх учителів фізичної культури. До форм навчання віднесено: аудиторні, позааудиторні заняття, самостійну роботу студентів, педагогічну практика. До методів - міні-лекції, бесіди, тренінги, рольові ігри, педагогічну рефлексію, проектування, проблемні завдання, портфоліо (конкретні ситуації).

Модель процесу формування індивідуального стилю діяльності вчителя фізичної культури будуємо на основі виявлених факторів (самопізнання, самооцінка, самосвідомість, професійна рефлексія, педагогічна майстерність як складова професійно-педагогічної культури), що проявляють себе на трьох послідовних 
етапах: орієнтовному, пошуковому, рефлексивному. У нашому дослідженні йдеться про етапи формування ІСПД майбутніх учителів фізичної культури в процесі педагогічної практики, формування здатності віднаходити й застосовувати оптимальні способи, методи і техніки розв'язання традиційних і суперечливих ситуацій у межах різних видів наскрізної педагогічної практики.

Модель сконструйовано таким чином, щоб кожний із наступних етапів формування ІСПД майбутніх учителів фізичної культури містив у собі елементи констатації стану ІСПД на початку етапу, певний «інкубаційний» період 3 описом механізмів формування ІСПД в межах даного етапу й характеристик, що свідчать про готовність переходу індивіда на новий етап, відповідно до умов, що виникають. У представленій моделі формування ІСПД майбутніх учителів фізичної культури враховано, що важливим завданням досліджуваного процесу є самоактуалізація й мотивація, які забезпечують професійну спрямованість, сприяють формуванню i розвитку професійної компетентності, рефлексії, самооцінці та корекції власних дій.

Часові межі кожного етапу формування ІСПД майбутніх учителів фізичної культури окреслюємо, 3 одного боку, індивідуально-психологічними властивостями студентів-практикантів, а 3 іншого, - специфікою конкретних умов життєдіяльності у процесі здобуття фахової освіти. Умови життєдіяльності визначають форму соціально значущих досягнень студента у зростанні його рівня готовності до формування ІСПД. На кожному з етапів динамічний інтегративний процес формування ІСПД має свої особливості, що пов'язані зі змінами особистісних i професійних характеристик, а тому спрямовуємо його на забезпечення нового рівня формування ІСПД і потреб у самореалізації студента в умовах сучасного вищого навчального закладу i в педагогічній практиці.

Завданням першого - орієнтовного emany - $€$ ознайомлення студентів із суттю поняття «індивідуальний стиль професійної діяльності» та розкриття його значення у педагогічній діяльності вчителя фізичної культури; осмислення значення ІСПД у цілісній системі фізкультурно-педагогічної діяльності і у професійній кар'єрі даного конкретного студента; самовизначення та мотивація потреби у виробленні індивідуального стилю професійної педагогічної діяльності вчителя фізичної культури.

На пошуковому етапі актуалізується розвиток когнітивно-процесуального, суб'єктно-діяльнісного компонентів. На формувальному етапі передбачено безпосереднє залучення майбутніх учителів фізичної культури до формування власного ІСПД. Студентам пропонується 3 великого переліку завдань обрати ті, виконання яких вони вважають корисними для власного професійного самовдосконалення i формування індивідуального стилю власної педагогічної діяльності.

Діагностичний блок відображає інтеграцію декількох інструментальних систем (структура стилю, критерії та рівні його сформованості), що дає змогу визначити ефект від реалізації моделі та порівняти отримані результати. Він охоплює критерії сформованості ІСПД (мотиваційний, когнітивний, діяльнісний, рефлексивноціннісний), показники та рівні (активний, адаптивний, пасивний). Серед критеріїв i показників ефективності педагогічної практики особливої уваги заслуговують такі, що засвідчують сформованість у студентів ІСПД, а саме:

-здатність прогнозувати наслідки застосування власного індивідуального стилю у педагогічної діяльності, розвиток індивідуально-особистісних якостей у вихованців з урахуванням перспектив їхнього становлення;

-спроможність розподіляти увагу одночасно між декількома видами діяльності, щоб тримати в полі зору всіх учнів; реагувати на прояви у них ознак стомлюваності, неуважності, нерозуміння; відзначати порушення дисципліни, стежити за власною поведінкою, змістом i формою викладу навчального матеріалу;

уміння вправно виконувати фізичні вправи, зважаючи на те, що рухові уміння, правильне демонстрування конкретної дії чи фізичної вправи визначає ефективність навчальної діяльності учнів. 
Тетяна Бугаєнко. Модель формування індивідуального стилю професійної діяльності майбутніх учителів фізичної культури у процесі педагогічної практки

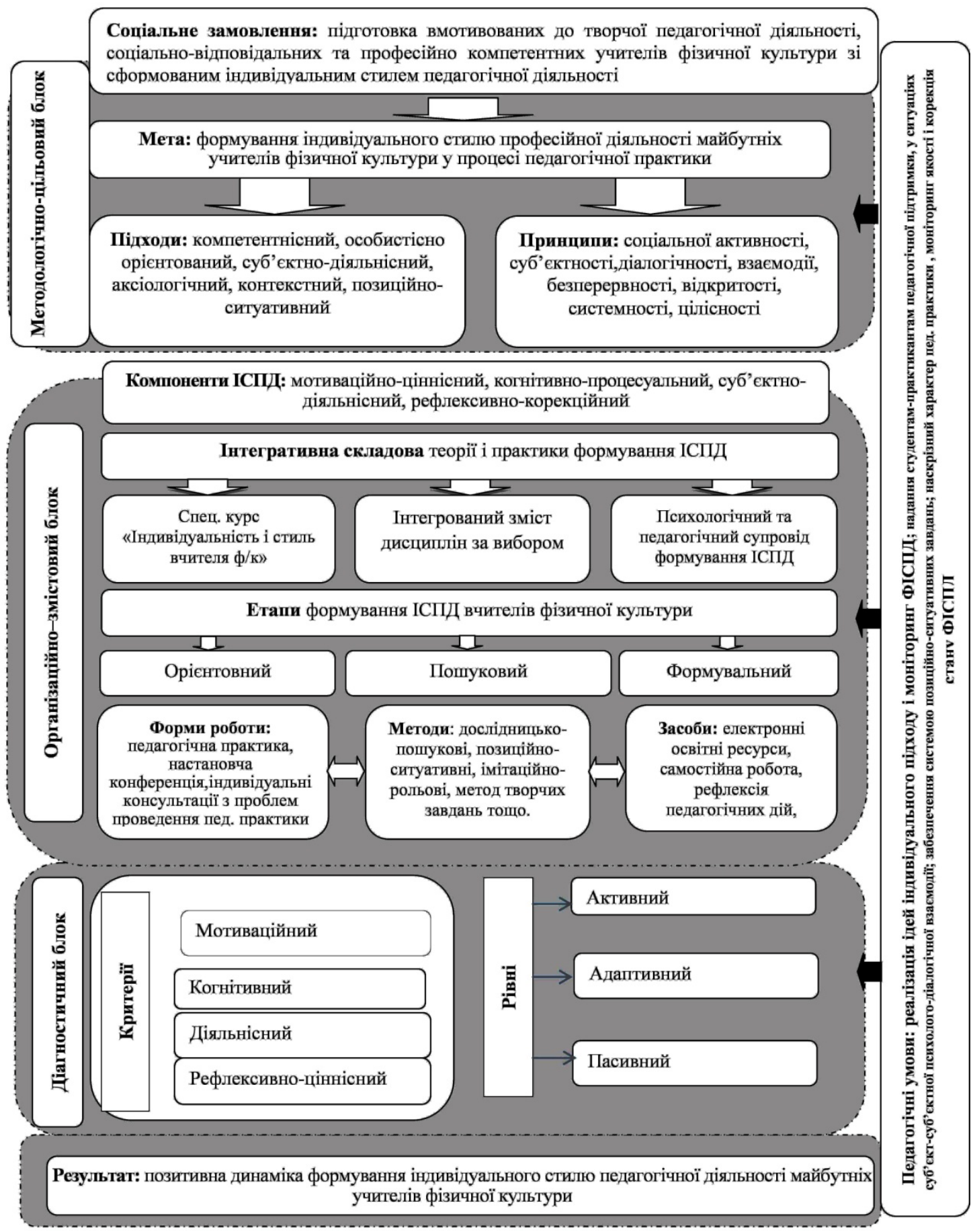

Puc. 1 .

Модель формування ІСПД майбутніх учителів фізичної культури

Висновок. Теоретичний аналіз праць 3 питань професійної підготовки майбутніх учителів фізичної культури та виконання психолого-педагогічних досліджень засвідчує, що в педагогічній теорії відсутні критерії, котрі дають змогу цілісно проаналізувати зміни у формуванні ІСПД майбутніх учителів фізичної культури, а також визначити ступінь впливу педагогічних умов, спрямованих на гуманізацію та індивідуалізацію їхньої професійної підготовки.

Модель формування індивідуального стилю професійної діяльності майбутніх 
учителів фізичної культури у процесі педагогічної практики представлена як структурно-діяльнісна, динамічна модель, яка, по-перше, містить у собі взаємопов'язані: мету, методологічні підходи, принципи, компоненти, етапи формування ІСПД; подруге, передбачає діяльнісний розвиток процесу, динамічність його моделі ілюструється через рівень розвитку процесу формування; по-трете, свідчить про керованість процесу через наявність в іiі структурі діагностичного інструментарію та критеріїв оцінки ефективності функціонування, які доводять доцільність упровадження методичних рекомендацій, моделі, результативність технології, виправдану послідовність етапів формування ІСПД, відображених у презентованій моделі.

Рівні сформованості компонентів ІСПД, стильова спрямованість майбутнього вчителя на результативність педагогічної практики визначає продуктивність його майбутньої педагогічної діяльності. При цьому стиль професійної діяльності вчителя фізичної культури зумовлений індивідуальними особливостями особистості, рівнем розвитку компетентностей і специфікою уроку фізичної культури. У цьому аспекті професійні компетентності $\epsilon$ основоположними у формуванні стилю професійної діяльності.

\section{Література}

1. Гончаренко С. У. Український педагогічний словник / С. У. Гончаренко. - К. : Либідь, 1997. - 376 с освіти» / Г.В.Бєлєнька. Київ, 2012. - 38 с.

2. Кондратова Л. Г. Модель підготовки вчителів до організації проектної діяльності учнів в умовах післядипломної педагогічної освіти / Л. Г. Кондратова // Педагогіка і психологія формування творчої особистості: проблеми i пошуки : зб. наук. праць. - Запоріжжя. - 2007. № 46. - С. 56-62.

3. Мишагин ориентированный профессиональной подготовки будущего учителя физической культуры : автореф. дис. ... канд. пед. наук. 13.00.01 - общая педагогика, история педагогики и образования / В.Н. Мишагин. Саратов, 2001. - 24 с.

4. Психологический словарь / Под ред. В. П. Зинченко, Б. Г. Мещерякова. - M. : Педагогика-Пресс, 1999. - 440 с.

5. Філософський енциклопедичний словник : энциклопедия / НАН України, Ін-т філософії ім. Г. С. Сковороди ; голов. ред. В. І. Шинкарук. Київ : Абрис, 2002. - 742 с.

\section{Реферат \\ Модель формирования индивидуального стиля профессиональной деятельности будущих учителей физической культуры в процессе педагогической практики}

Татьяна Бугаенко, преподаватель кафедры здоровья, физической терапии, реабилитации и эрготерапии

Сумского государственного педагогического университета

КЛЮЧЕВЫЕ СЛОВА:

профессиональные

компетентности,

педагогический

работник,

методист,

научно-методическая

работа, непрерывное

образование,

межкурсовой период,

совершенствование

профессионального

мастерства, повышение

квалификации им. А. С. Макаренко

В данной статье рассматривается содержание модели формирования индивидуального стиля профессиональной деятельности будущих учителей физической культуры в процессе педагогической практики. Определены и обоснованы педагогические условия, которые непосредственно влияют на эффективность этого процесса. Спроектированную модель детализировано составными методологически-целевого, организационно-содержательного и диагностического блоков, сформированных с учетом цивилизационных запросов и социального заказа. Методологически-целевой блок содержит основную идею, которой подчинены все составные элементы модели, определяет способность видеть общий ход процесса и опережающе корректировать его. Он определяет стратегию реализации модели и включает в себя: цель, методологические принципы и универсальные подходы становления стиля. Организационно-содержательный блок раскрывает компонентный состав индивидуального стиля профессиональной деятельности; комплекс условий, форм, методов и средств работы, которые 
Тетяна Бугаєнко. Модель формування індивідуального стилю професійної діяльності майбутніх учителів фізичної культури у процесі педагогічної практки

обеспечивают результативность реализации модели. Также в данном блоке характеризирована совокупность внешних и внутренних причин, двигательных сил и явлений, отдельные черты процесса становления индивидуального стиля деятельности будущего учителя. Раскрыто содержание этапов формирования индивидуального стиля профессиональной деятельности будущих учителей физической культуры в процессе педагогической практики, которые построены таким образом, чтобы каждый из последующих этапов содержал элементы констатации состояния стиля. Временные границы каждого этапа очерчены, с одной стороны, индивидуально-психологическими свойствами студента-практиканта, а с другой, - спецификой конкретных условий жизнедеятельности в процессе получения профессионального образования. Диагностический блок направлен на определение эффекта от реализации модели и сравнение полученных результатов. Он отображает интеграцию таких инструментальных систем, как: структура стиля, критерии и уровни его сформированности, дает представление о механизмах реализации разработанной модели через взаимосвязь диагностических процедур, определение этапов становления стиля и критериально направленное влияние организационно-педагогических условий на компоненты индивидуального стиля.

\section{Abstract \\ Formation model for future physical education teachers’ professional activity of individual style under teaching internship course}

Tetyana Bugaenko, a teacher of the health, physical therapy, rehabilitation and ergotherapy

department of Sumy State Pedagogical University named after A.S. Makarenko

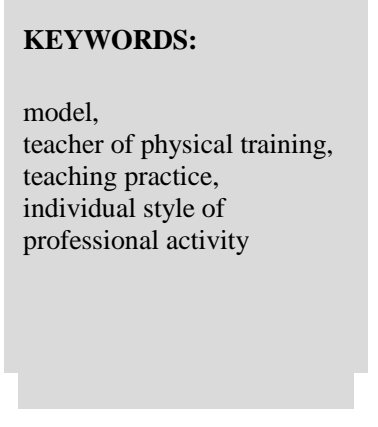

This article deals with the content of the model of formation of the individual style of professional activity of future physical training teachers in the process of teaching practice. The pedagogical conditions that directly influence the effectiveness of this process are determined and substantiated. The designed model is specified by the components of the methodology and target, organization and content and diagnostic blocks, which reflect the purpose of the educational process, defined by taking into account civilization needs and social order. The block of methodology and target contains the basic idea, which subordinates all the constituent elements of the model and determines the ability to observe the overall progress and adjust it in advance. It defines the strategy for the model implementation and includes the purpose, methodological principles and universal approaches to the style formation. The block of organization and content reveals the component composition of the individual style of professional activity; a complex of the conditions, forms, methods and means of work that ensure the effectiveness of the model implementation. A set of external and internal causes, driving forces and phenomena, some features of the process of establishment an individual style of the future teacher are described in this block. The content of the stages of the formation of the individual style of professional activity of future teachers of physical culture in the process of pedagogical practice is revealed. Time limits of each stage are outlined, on the one hand, by the individual psychological features of each trainee, and on the other hand, the specifics of specific living conditions in the process of obtaining professional education.

The diagnostic block is aimed at determining the effect of the implementation of the model and comparison of the results. It reflects the integration of such instrumental systems as the structure of style, the criteria and levels of its maturity, gives an idea of the mechanism of implementation of the developed model through the interconnection of diagnostic procedures, determines the steps of the style formation and the criterion directed influence of organizational and pedagogical conditions on the components of the individual style.

\section{References}

1. Goncharenko S. U. Ukrainian Pedagogical Dictionary / S. V. Goncharenko. - K. : Lybid, 1997. 376 p.
2. Kondratova L. G. The model of teacher training for the organization of project activity of students in postgraduate pedagogical education / 
L. G. Kondratova // Pedagogics and psychology of the formation of a creative person: problems and searches: sb. sciences works. - Zaporizhzhia. - 2007. - № 46. P. 56-62.

3. Mishagin V. N. Personality-oriented approach to the organization of vocational training of the future teacher of physical culture: author's abstract. dis ... candidate ped. sciences 13.00.01 - general pedagogy, history of pedagogy and education / V. N. Mishagin. - Saratov, 2001. - 24 p.

4. Psychological Dictionary / Ed. V.P. Zinchenko, B. G. Meshcheryakova. - M. : Pedagogics-Press, 1999. - 440 p.

5. Philosophical Encyclopedic Dictionary: Encyclopedia / NAS of Ukraine, Institute of Philosophy after G.S. Skovoroda; chief ed. V. I. Shynkaruk. - Kyiv : Abris, 2002. - 742 p.

\section{МОДЕЛЬ ПРОФЕСІЙНОГО САМОВДОСКОНАЛЕННЯ КЕРІВНИКІВ ЗАКЛАДІВ ПРОФЕСІЙНОЇ (ПРОФЕСІЙНО-ТЕХНІЧНОЇ) ОСВІТИ У ПРОЦЕСІ ПІДВИЩЕННЯ КВАЛІФІКАЦЇ̈}

Вікторія Купрісвич,

стариий викладач кафедри публічного адміністрування та менеджменту освіти ДВНЗ «Університет менеджменту освіти» НАПН Украӥни.

ORCID: 0000-0002-8196-8309

ключОВІ СЛОВА:
модель,
післядипломна освіта,
професійне
самовдосконалення,
підвищення
кваліфікації,
керівник професійного
(професійно-
технічного)
навчального закладу

Постановка проблеми. Характерною ознакою сьогодення стали зміни - неперервні та стрімкі. Вони докорінно змінюють життя людини, умови праці, потребують нових якостей, умінь, нової філософії життя: професійної і соціальної мобільності, безперервної освіти та постійного професійного самовдосконалення.

Процес модернізації системи освіти оновлює діяльність керівника закладу професійної (професійно-технічної) освіти (далі - керівник ЗП(ПТ)О). Для успішного управління закладом професійно (професійнотехнічної) освіти в нинішніх соціальноекономічних умовах потрібні якісні зміни і в мисленні керівника ЗП(ПТ)О. Він має чітко усвідомлювати необхідність безперервного професійного зростання та підвищення управлінської кваліфікації. Керівник ЗП(ПТ)О як суб'єкт управлінської діяльності впродовж свого свідомого життя повинен прагнути самореалізуватися через самовиховання, саморозвиток, самовдосконалення та самоорганізацію.

Саме післядипломна освіта, яка $\epsilon$ однією 3 найважливіших ланок безперервної освіти, зможе в цьому допомогти. Вона доповнює та розширює базову професійну освіту, створює креативне середовище для саморозвитку та самовдосконалення.

Нові тенденції в розвитку освіти зумовлюють необхідність розробки мобільної багатовимірної моделі професійного самовдосконалення керівників ЗП(ПТ)О в 